\title{
Antifungal activity of Oregano (Origanum vulgare L.) extract on the growth of Fusarium and Penicillium species isolated from food
}

\author{
Sunčica D. Kocić-Tanackov ${ }^{1}$, Gordana R. Dimić ${ }^{1}$, llija J. Tanackov ${ }^{2}$, Dušanka J. Pejin ${ }^{1}$, Ljiljana V. Mojović ${ }^{3}$, \\ Jelena D. Pejin ${ }^{1}$ \\ ${ }^{1}$ University of Novi Sad, Faculty of Technology, Novi Sad, Serbia \\ ${ }^{2}$ University of Novi Sad, Faculty of Technical Sciences, Novi Sad, Serbia \\ ${ }^{3}$ University of Belgrade, Faculty of Technology and Metallurgy, Belgrade, Serbia
}

\begin{abstract}
The effect of the oregano extract (Origanum vulgare L.) on the growth of Fusarium and Penicillium species isolated from cakes and ready-for-use fresh salads from different kinds of vegetables was investigated. The contents of the active component of extract were identified by GC-MS and they include: carvacrol (34.2\%), carvone (18.5\%), p-cimene $(8.05 \%)$, thymol (3.74\%). The oregano extract showed the ability to reduce mould growth at all applied concentrations. Stronger inhibitory effect on the growth of Penicillium species, contrary to Fusarium, was determined. At extract concentration of $2.50 \mathrm{~mL} / 100$ $\mathrm{mL}$, growth of $P$. aurantiogriseum, $P$. glabrum and $P$. brevicompactum was completely inhibited during 14 days of incubation. At the same concentration, growth of Fusarium proliferatum was inhibited by $81.71 \%, F$. oxysporum by $85.84 \%$, F. verticillioides by $86.50 \%, P$. chrysogenum by $86.2 \%$ and $F$. subglutinans by $88.85 \%$.
\end{abstract}

Keywords: Oregano extract; antifungal activity; Fusarium spp.; Penicillium spp.

\section{SCIENTIFIC PAPER}

UDC 635.71:547.9:615.282

Hem. Ind. 66 (1) 33-41 (2012)

doi: 10.2298/HEMIND110614073K

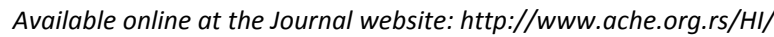

Moulds comprise a large group of microorganisms, which are frequent contaminants, and causes of spoilage in many food commodities. Fusarium species are field moulds, which require higher substrate moisture (20-21\%) and lower temperatures for growth and commonly contaminate plants on fields. They are frequent contaminants of cereals (corn, barley, wheat, oats, rye, rice, etc.), cereal products (flour, bread, cakes, etc.), fruits and vegetables [1-4]. Penicillium species are storage moulds with lower requirements regarding substrate moisture (13-18\%), but higher temperature requirements and are frequently isolated from stored products [5-8]. Enormous economic damages take place as a consequence of food deterioration caused by metabolic activity of microorganisms [7]. In addition, species possessing the genetic base for mycotoxin production can biosynthesize zearalenone, trichothecenes, fumonisins, monilioformin, fusarin C, etc. (Fusarium spp.), ochratoxin A, penicillic acid, verrucosidin, patulin, nephrotoxic glycopeptides, roquefortine $C$, chrysogine, penitrem A, etc. (Penicillium spp.) [9-11]. The consumption of food contaminated with mycotoxins has been associated with various diseases in humans, livestock and domestic animals. They have been recog-

Correspondence: S. Kocić-Tanackov, Food Microbiology, Faculty of Technology, University of Novi Sad, Bulevar cara Lazara 1, 21000 Novi Sad, Serbia.

E-mail: suncicat@uns.ac.rs

Paper received: 14 June, 2011

Paper accepted: 3 October, 2011 nized as causes of cytotoxicity, hepatotoxicity, teratogenicity, mutagenicity, neurotoxicity, etc. $[9,11]$.

Several strategies have been used in controlling the fungal growth and mycotoxin biosynthesis in food products. However, today consumers increasingly demand that their food is minimally processed without synthetic preservatives and additives, because of their possible harmful effects on human health. The problem that the food industry now faces is how to produce food that will satisfy these criteria and also be safe to use. It is known that certain types of spice plants have antimicrobial properties. Therefore, essential oils, extracts, oleoresins and their main components extracted from natural herbs as antimicrobial agents attracted attention as one of the possible solutions for controlling the fungal growth and mycotoxin biosynthesis in food that are not toxic in contrast to chemical additives [12-17].

Oregano is a widely used spice in the food industry. It is mainly used for its aromatic properties with a primary role to enhance the taste and aroma of foods. Due to high content of oleanolic, ursolic, caffeic, rosemarinic, lithospermic acids, flavonoids, hydroquinones, tannins, and phenolic glycosides, oregano has been shown to exhibit antioxidative and antimicrobial activity.

The objective of this work was to study the antifungal potential of commercial oregano (Origanum vulgare L.) extract, intended for usage in food, against some Fusarium and Penicillium species isolated from cakes and ready-for-use fresh salads from different kinds of vegetables. 


\section{MATERIALS AND METHODS}

\section{Oregano extract}

For antifungal activity testing, a commercially available food grade oregano (Origanum vulgare L.) extract was provided from ETOL "Tovarna arom in eteričnih olj d.d.", Celje, Slovenia.

\section{Determination of oregano extract composition}

The composition of extracts was determined by gas chromatography-mass spectrometry (GC-MS) analyses. The GC-MS analysis was carried out on a Varian T2100 GC-MS instrument equipped with data processor. A fused silica capillary column VF-5MS $(30 \mathrm{~m} \times 0.25 \mathrm{~mm}$ i.d., $0.25 \mu \mathrm{m}$ film thickness, Varian) was used for the separation of the sample components. The carrier gas ultra pure helium was passed through moisture and oxygen traps with constant flow rate of $0.62 \mathrm{~cm}^{3} / \mathrm{min}$. The following temperature program was used: injector temperature $230{ }^{\circ} \mathrm{C}$, initial temperature $40{ }^{\circ} \mathrm{C}$ (held 5 min), temperature increase $5{ }^{\circ} \mathrm{C} / \mathrm{min}$ to $200^{\circ} \mathrm{C}$ and held at this temperature for $25 \mathrm{~min}$. The mass spectrometer was operated in the electron ionization mode. The data acquisition was carried out in the scan mode (range 50-550 m/z). The injection volume was $1 \mu \mathrm{l}$. The compounds were identified by matching the mass spectra with NIST Mass Spectra Library stored in the GC-MS database.

\section{Fungal strains}

As testing microorganisms, the following fungal strains from the genera Fusarium and Penicillium were used: F. oxysporum Schlecht., F. proliferatum (Matsushima) Nirenberg, F. subglutinans (Wollenw. \& Reinking) Nelson, Toussoun \& Marasas and F. verticillioides (Sacc.) Nirenberg (syn. F. moniliforme Sheld.), P. aurantiogriseum Dierckx, P. brevicompactum Dierckx, P. glabrum (Wehmer) Westling, $P$. chrysogenum Thom. The fungal cultures were isolated from cakes and ready-for-use fresh salads from different kinds of vegetables and identified according to determination keys described by Leslie and Summerell [3], Lević [4], Samson and Frisvard [6], and Samson et al. [18]. The isolated cultures were maintained on Potato Dextrose Agar (PDA) (Merck, Darmstadt) at $4{ }^{\circ} \mathrm{C}$ as a part of the collection of the Laboratory for Food Microbiology at the Faculty of Technology, University of Novi Sad, Serbia.

\section{Efficacy of oregano extract on the growth of Fusarium and Penicillium species}

The agar plate method was applied in testing of antifungal activity of oregano extract. The basic medium for antifungal tests was PDA (Merck, Darmstadt). The medium was divided into equal volumes $(150 \mathrm{~mL})$, poured into Erlenmeyer $(250 \mathrm{~mL})$ flasks and autoclaved at $121{ }^{\circ} \mathrm{C}$ for $15 \mathrm{~min}$. Concentrations of $0,0.35,0.70$,
1.50 and $2.50 \mathrm{~mL} / 100 \mathrm{ml}$ were tested. The extracts were added to the medium after cooling to $45{ }^{\circ} \mathrm{C}$. The culture medium was poured into sterile Petri dishes $(\varnothing$ $9 \mathrm{~cm}), 12 \mathrm{~mL}$ into each plate.

Seven-day fungal cultures grown on PDA were used to prepare fungal spore suspension tests. Suspensions of funal spores were prepared in a medium containing $0.5 \%$ Tween 80 and $0.2 \%$ agar in distilled water and adjusted to $10^{6}$ spores $/ \mathrm{mL}$ using a haemocytometer. For each extract dose and fungi species, including the controls, plates were centrally inoculated with $1 \mu$ of a spore suspension $\left(10^{3}\right.$ spores $\left./ \mathrm{mL}\right)$ using an inoculation needle. After inoculation, the Petri plates were closed with a parafilm.

The efficacy of the treatment was evaluated by daily measurement of the diameter of the radial colony growth during 14 days of incubation at $25 \pm 2{ }^{\circ} \mathrm{C}$. The parafilms were removed from the Petri dishes without fungal growth after 14 days, and they were further incubated up to $30^{\text {th }}$ day. If there were no observable growth during this period, fungal spores were transferred using a wet cotton swab to the PDA medium free from extract and were incubated for 5 days at $25 \pm 2{ }^{\circ} \mathrm{C}$ to confirm the fungicidal effect (MFC).

The inhibitory effect of the oregano extract was calculated following the formula:

$I(\%)=100(C-T) / C$

where $I$ is inhibition, $C$ is colony diameter on the control plate and $T$ is colony diameter on the test plate [19].

\section{Monitoring of macroscopic and microscopic changes in moulds}

Changes in macroscopic and microscopic features of moulds were observed and compared to the controls. The macroscopic and microscopic features were observed using a stereoscopic binocular microscope (Technival 2, Carl Zeiss) and microscope (Aristoplan, Leitz), respectively.

\section{Statistical analysis}

Determination of the effect of oregano extract on the growth of Fusarium and Penicillium species was carried out in 3 series and 2 replications. Microsoft Statistica ${ }^{\circledR} 4.5$ (Microsoft, USA) was used to calculate means and standard deviations. Significant differences between the colony growth inhibition values assessed on the fourteenth day of the testing were determined by Duncan's multiple range test $(p<0.05)$, following one-way ANOVA procedure. 


\section{RESULTS AND DISCUSSION}

\section{Extract composition}

The constituents of the oregano extract are shown in Table 1. A total of 20 components were identified, with major components being carvacrol (34.20\%), carvone $(18.05 \%), p$-cymene $(8.05 \%)$, thymol (3.74\%) limonene $(3.36 \%), \gamma$ terpinene $(2.35 \%)$.

The majority of researchers named carvacrol and thymol as the main compounds associated with the antimicrobial activity of oregano [20-23]. p-Cymene and $\gamma$ terpinene were evaluated as weaker antimicrobial agents when compared to carvacrol and thymol, although they are their bioprecursors [24,25].

\section{Effect of oregano extract on the growth of Fusarium and Penicillium species}

The oregano extract at the tested concentrations showed a capacity to reduce or inhibit the growth of Fusarium and Penicillium species. The inhibitory effect of the extract increased proportionally with concentration and was also affected by treatment duration. Growth rate and colony growth inhibition of tested moulds in the presence of oregano extract are presented in Figures 1-8. Table 2 presents the results of mould inhibition assessed on fourteenth day of exposure to oregano extract.
During 14 days of incubation, the lowest concentration of oregano extract significantly inhibited the growth of $F$. proliferatum $(24.06 \%), F$. oxysporum (23.22\%) and F. subglutinans $(22.30 \%)$ whereas its effect was negligible to $P$. glabrum $(3.07 \%)$ and $P$. chrysogenum (5.99\%). At $0.70 \mathrm{~mL} / 100 \mathrm{~mL}$ extract concentration the inhibition of fungal growth ranged from $10.27 \%$ (P. glabrum) to $54.47 \%$ ( $P$. aurantiogriseum). The extract concentration of $1.50 \mathrm{~mL} / 100 \mathrm{~mL}$ exhibited the highest inhibitory effect against the growth of $F$. subglutinans (76.45\%), P. aurantiogriseum (76.43\%), F. verticillioides $(72.61 \%)$ and $F$. proliferatum $(72.21 \%)$. At this concentration, the inhibitory activity against other tested moulds ranged from $53.74 \%$ (P. glabrum) to $62.86 \%$ ( $P$. brevicompactum). At $2.50 \mathrm{~mL} / 100 \mathrm{~mL}$, the growth of $P$. aurantiogriseum, $P$. glabrum and $P$. brevicompactum was totally inhibited after 14 days of incubation. The colony growth was reduced by $86.2 \%$ in $P$. chrysogenum, $81.71 \%$ in $F$. proliferatum, $85.84 \%$ in $F$. oxysporum, $86.50 \%$ in $F$. verticillioides and $88.85 \%$ in $F$. subglutinans (Figures 1-8, Table 2).

Increasing concentrations of oregano extract $(0.70$, 1.50 and $2.50 \mathrm{~mL} / 100 \mathrm{~mL}$ ) caused an absence or delay in spore germination and showed different inhibitory effects.

At extract concentration of $0.70 \mathrm{~mL} / 100 \mathrm{~mL}$, spore germination in $P$. aurantiogriseum was delayed for one day in relation to the control whereas it was unaffected

Table 1. Chemical composition of Oregano extract

\begin{tabular}{|c|c|c|c|c|}
\hline Peak & Compound & Percentage $^{a}$ & $R T^{b} / \min$ & Identification method \\
\hline 1 & $\alpha$-Thujene & 0.23 & 10.259 & $\mathrm{GC}-\mathrm{MS}^{\mathrm{C}}$ \\
\hline 2 & $\alpha$-Pinene & 0.28 & 10.512 & GC-MS \\
\hline 3 & Camphene & 0.31 & 11.123 & GC-MS \\
\hline 4 & Myrcene & 0.31 & 12.656 & GC-MS \\
\hline 5 & $\alpha$-Phellandrene & 0.97 & 13.221 & GC-MS \\
\hline 6 & $\alpha$-Terpinene & 0.20 & 13.601 & GC-MS \\
\hline 7 & $p$-Cymene & 8.05 & 13.895 & GC-MS \\
\hline 8 & Limonene & 3.36 & 14.034 & GC-MS \\
\hline 9 & $\gamma$-Terpinene & 2.35 & 15.042 & GC-MS \\
\hline 10 & Linalol & 1.51 & 16.521 & GC-MS \\
\hline 11 & Borneole & 0.22 & 18.840 & $\mathrm{GC}-\mathrm{MS}$ \\
\hline 12 & 4-Terpineole & 0.05 & 19.048 & GC-MS \\
\hline 13 & Dill ether & 1.69 & 19.184 & GC-MS \\
\hline 14 & $\alpha$-Terpineole & 0.29 & 19.558 & GC-MS \\
\hline 15 & Dihydrocarvone & 0.24 & 19.751 & GC-MS \\
\hline 16 & Carvone & 18.05 & 20.934 & GC-MS \\
\hline 17 & Thymol & 3.74 & 22.537 & GC-MS \\
\hline 18 & Carvacrol & 34.20 & 22.766 & GC-MS \\
\hline 19 & Triacetin & 22.91 & 23.619 & GC-MS \\
\hline 20 & $\beta$-Caryophyllene & 0.90 & 25.658 & GC-MS \\
\hline 21 & Other compounds & 0.14 & - & GC-MS \\
\hline
\end{tabular}

aelative area percentage; ${ }^{b}$ retention time on VF-5MS column; ${ }^{c}$ gas chromatography-mass spectrometry 

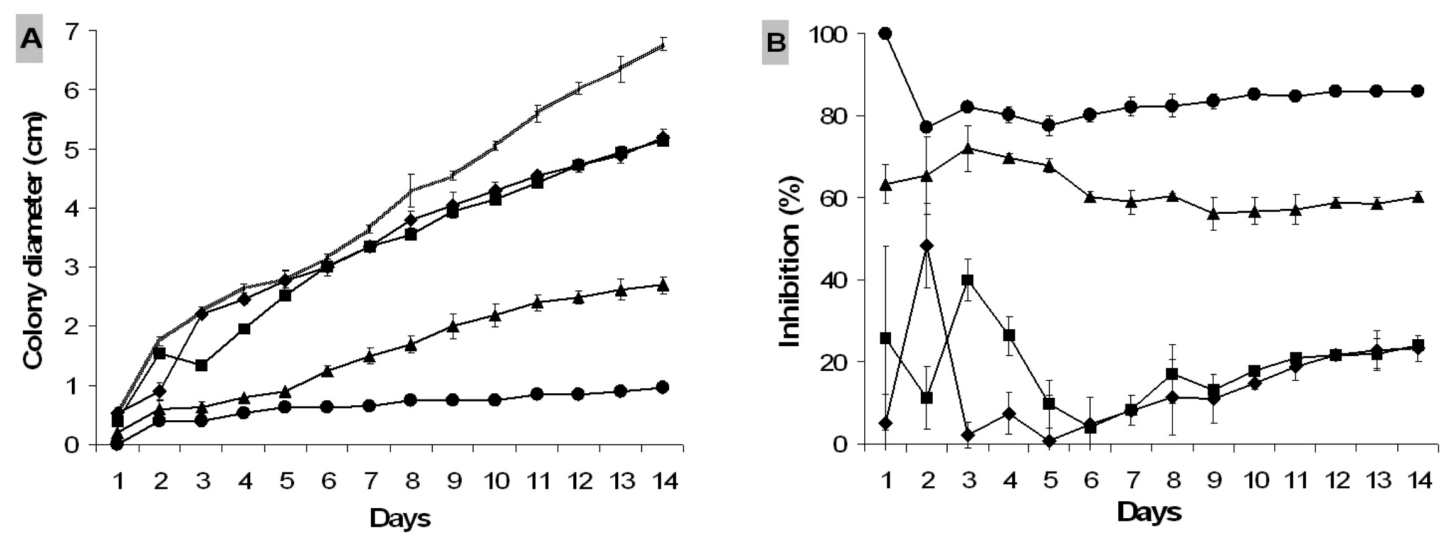

Figure 1. Growth rate (A) and colony growth inhibition (B) of F. oxysporum; control ( $\infty \boldsymbol{\infty}), 0.35(\bullet), 0.70(\boldsymbol{\nabla})$, 1.50 (4) and $2.50 \mathrm{~mL} / 100 \mathrm{~mL}(\bullet)$.
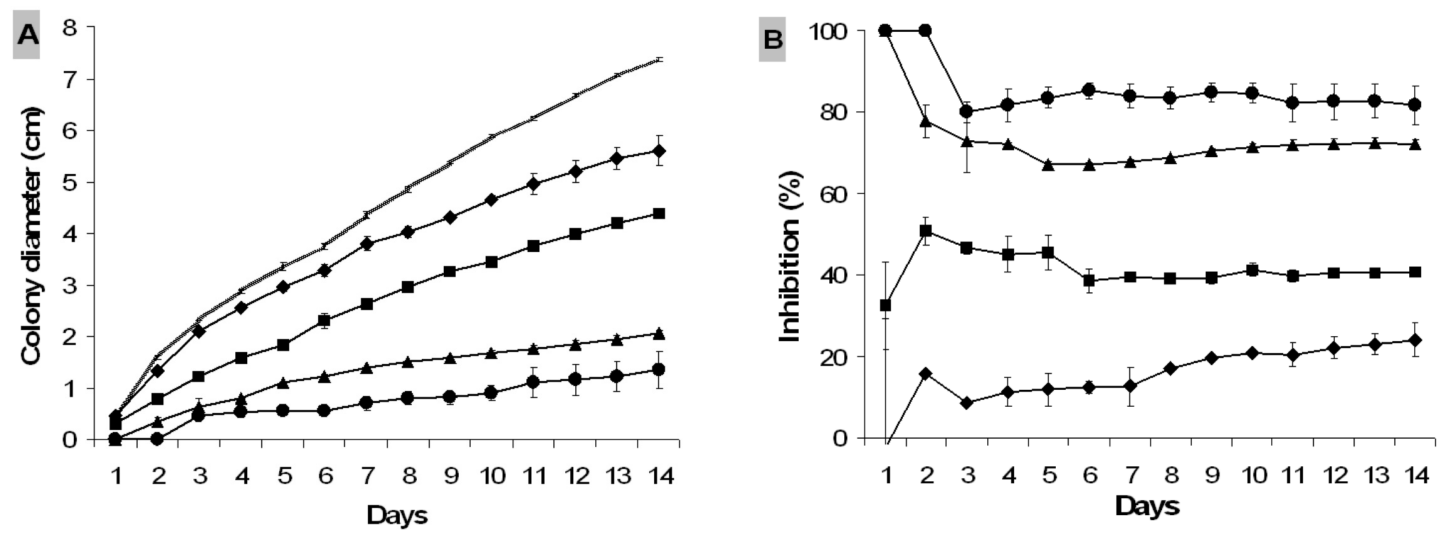

Figure 2. Growth rate (A) and colony growth inhibition (B) of F. proliferatum; control (wo), $0.35(\Delta), 0.70(\boldsymbol{\nabla})$, 1.50 (4) and $2.50 \mathrm{~mL} / 100 \mathrm{~mL}(\bullet)$.
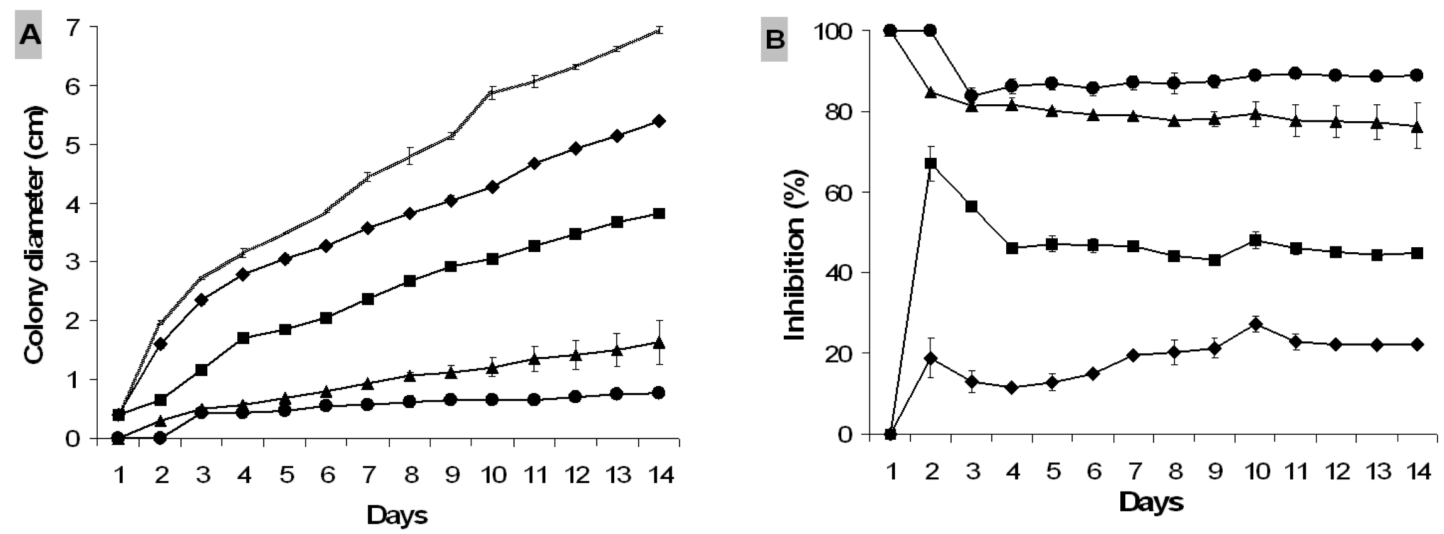

Figure 3. Growth rate (A) and colony growth inhibition (B) of F. subglutinans; control (w), $0.35(\boldsymbol{)}), 0.70(\boldsymbol{\nabla})$, 1.50 (4) and $2.50 \mathrm{~mL} / 100 \mathrm{~mL}(\bullet)$.

in other assayed species. At $1.50 \mathrm{~mL} / 100 \mathrm{~mL}$ concentration, the colony growth of $P$. aurantiogriseum was delayed for 3 days, $P$. brevicompactum for 2 days, $P$. glabrum, F. proliferatum and $F$. subglutinans for one day. During 30 days of incubation at $2.50 \mathrm{~mL} / 100 \mathrm{~mL}$ extract concentration, the growth of $P$. aurantiogriseum was not observed. This concentration delayed the growth of $P$. brevicompactum for 23 days and $P$. glabrum for 17 days. The growth of $P$. chrysogenum, $F$. proliferatum, F. subglutinans was observed on the third day and $F$. oxysporum after 2 days of incubation. This extract concentration was MFC for $P$. aurantiogriseum and MIC for P. brevicompactum and P. glabrum. 

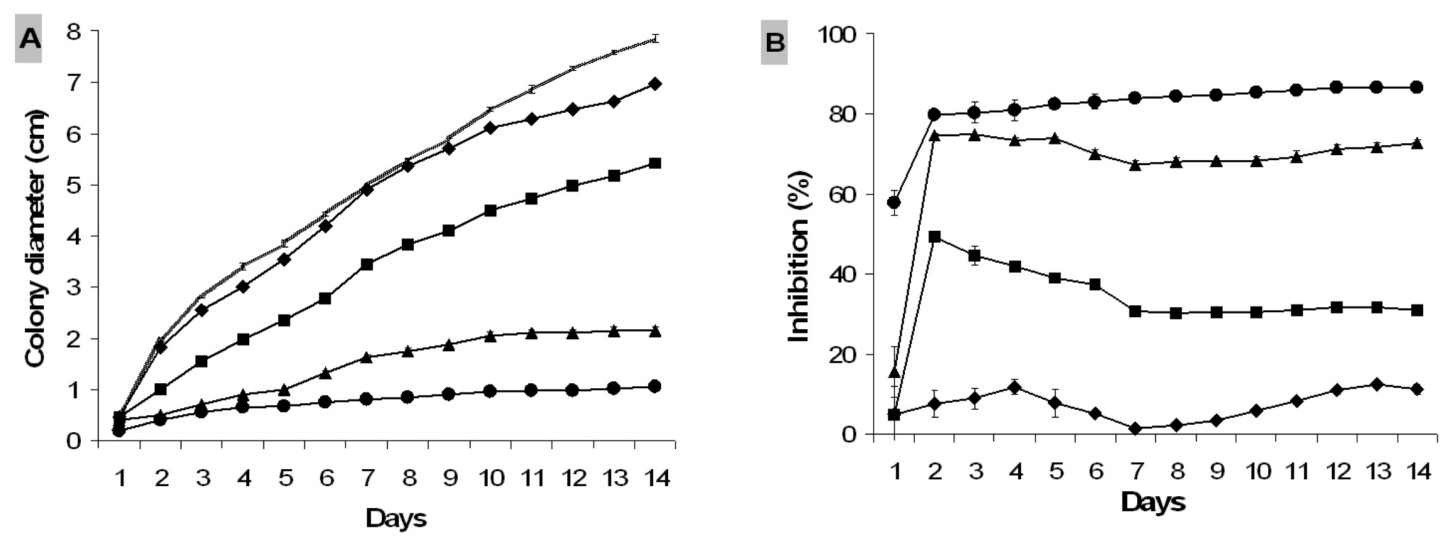

Figure 4. Growth rate (A) and colony growth inhibition (B) of F. verticillioides; control ( $\infty \times), 0.35(\bullet), 0.70(\boldsymbol{\nabla})$, 1.50 (4) and $2.50 \mathrm{~mL} / 100 \mathrm{~mL}(\bullet)$.
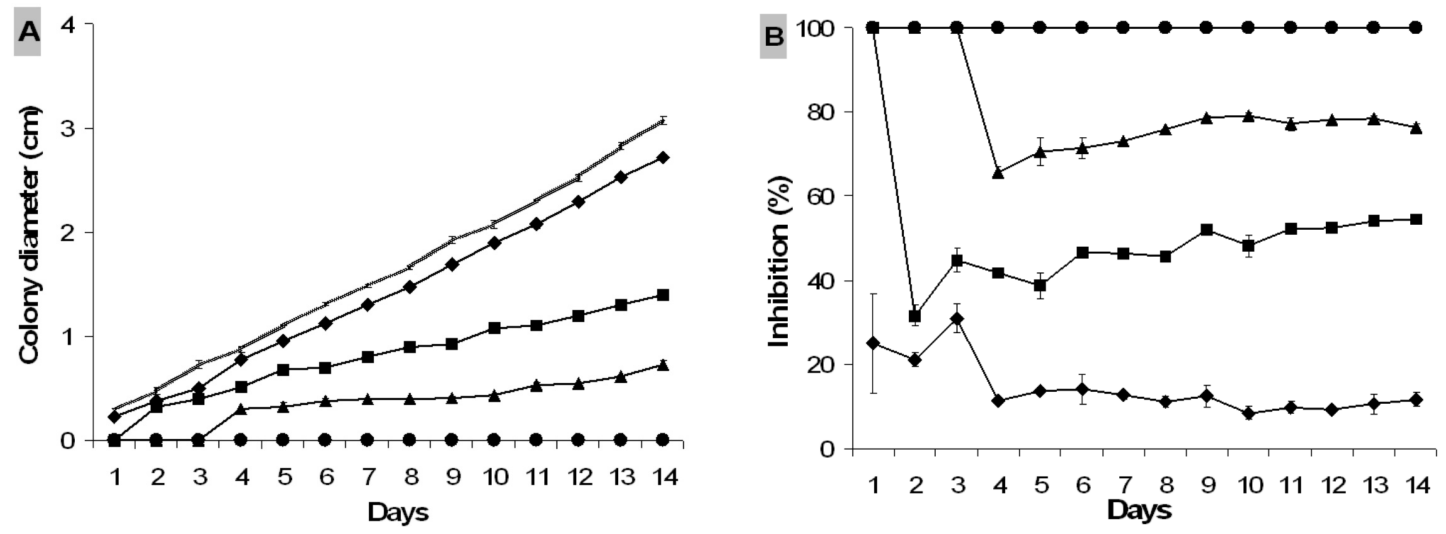

Figure 5. Growth rate (A) and colony growth inhibition (B) of P. aurantiogriseum; control (w), $0.35(\Delta), 0.70(\boldsymbol{\nabla})$, 1.50 ( $\Delta)$ and $2.50 \mathrm{~mL} / 100 \mathrm{~mL}(\bullet)$.
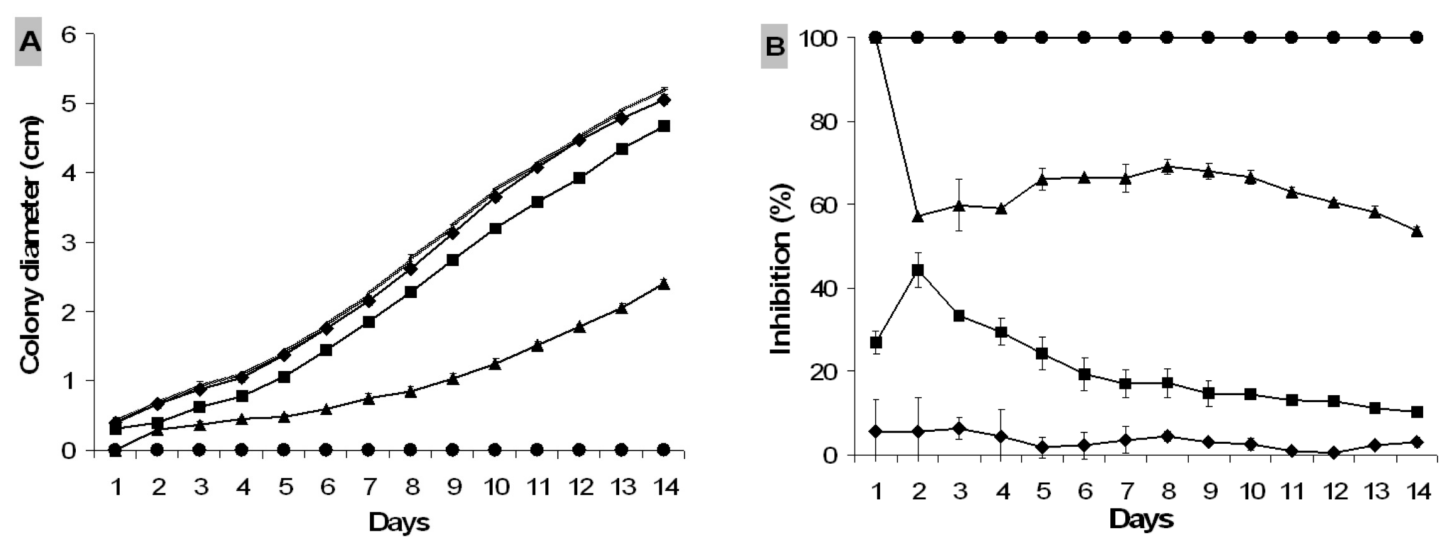

Figure 6. Growth rate $(A)$ and colony growth inhibition (B) of P. glabrum; control (w), $0.35(\bullet), 0.70(\boldsymbol{\nabla})$, 1.50 (4) and $2.50 \mathrm{~mL} / 100 \mathrm{~mL}(\bullet)$.

Colony growth reduction induced by increased Oregano extract concentrations was more evident in Penicillium species than in Fusarium species, which implies their higher sensitivity (Figures 1-8).

Besides the colony growth reduction effect, the tested oregano extract caused changes in fungal macro and micromorphology. At higher concentrations (1.50 and $2.50 \mathrm{~mL} / 100 \mathrm{~mL}$ ), the formation of uncharacteristic colonies with centre elevation, granular structure and diminished conidiation ( $P$. brevicompactum, P. chrysogenum, F. oxysporum) occurred. Moreover, hyphae deformations with frequent occurrence of fragmentations and thickenings or bending, deviations of reproductive organs (occurrence of irregular vesicle frequently without 

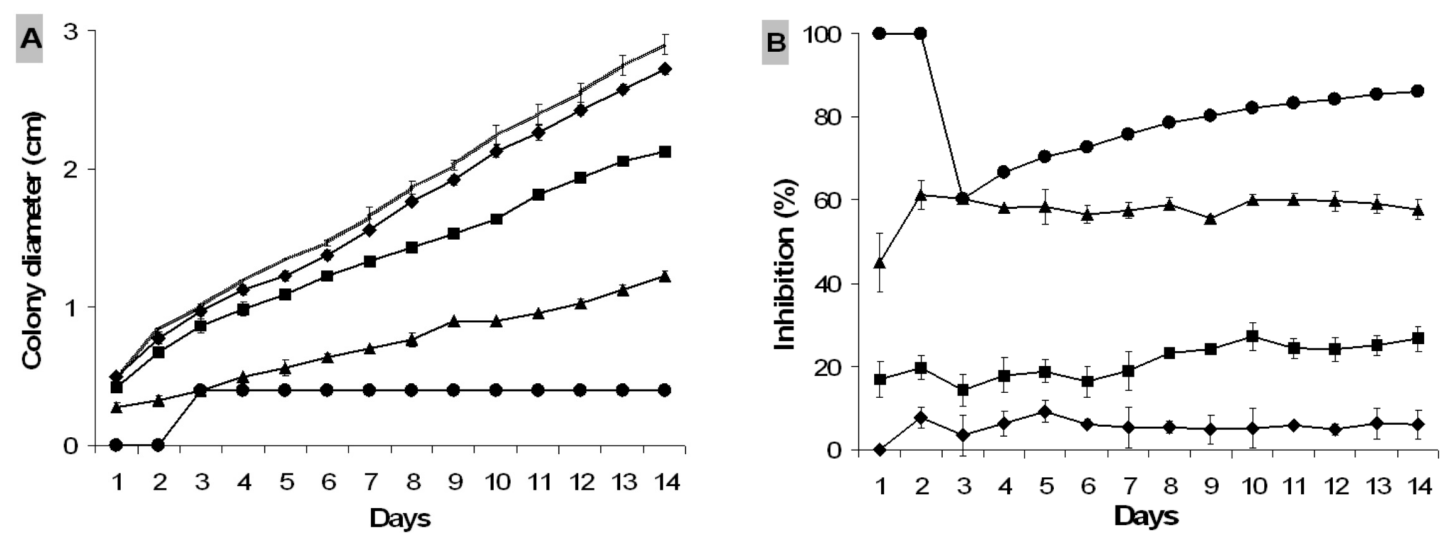

Figure 7. Growth rate $(A)$ and colony growth inhibition (B) of P. chrysogenum; control (⿻心), $0.35(\diamond), 0.70(\boldsymbol{\nabla})$, 1.50 ( 4$)$ and $2.50 \mathrm{~mL} / 100 \mathrm{~mL}(\bullet)$.
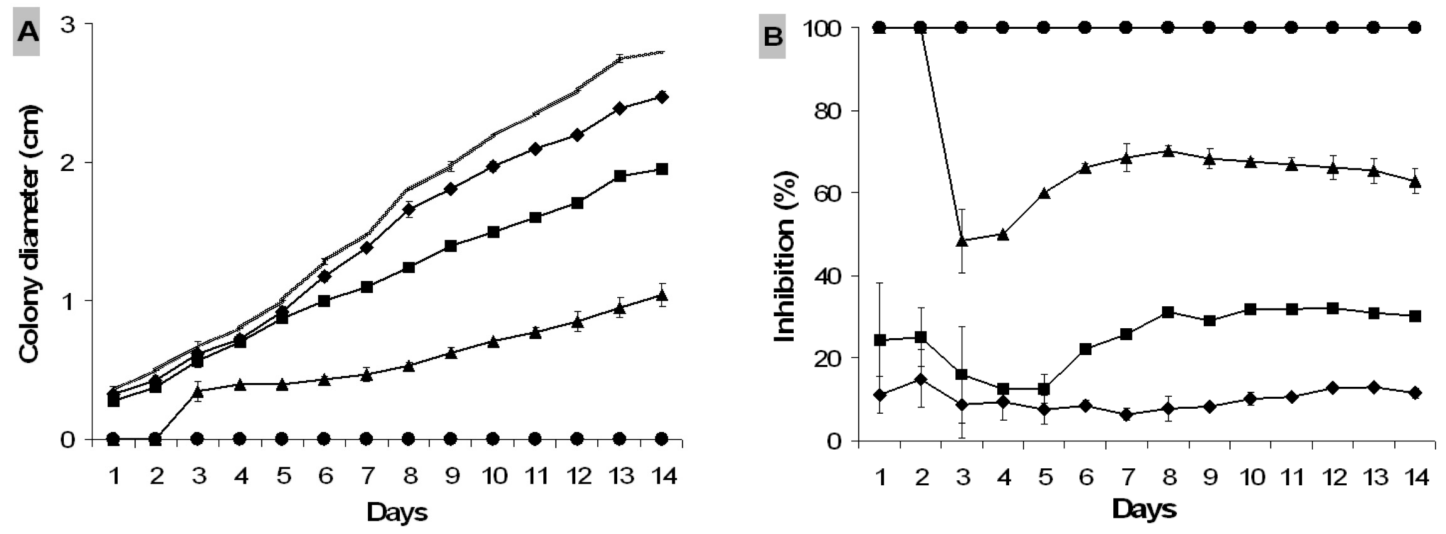

Figure 8. Growth rate (A) and colony growth inhibition (B) of P. brevicompactum; control (\%), $0.35(\checkmark), 0.70(\boldsymbol{\nabla})$, 1.50 ( 4$)$ and $2.50 \mathrm{~mL} / 100 \mathrm{~mL}(\bullet)$.

Table 2. Colony growth inhibition (\%) of tested moulds after 14 days of incubation. Values followed by the same small letter (a-d) within the same column are not the significantly different $(p>0.05)$ according to Duncan's multiple rang test. Values followed by the same big letter $(A-E)$ within the same row are not the significantly different $(p>0.05)$ according to Duncan's multiple rang test

\begin{tabular}{lcccc}
\hline \multirow{2}{*}{ Moulds } & \multicolumn{4}{c}{ Concentration of oregano extract, $\mathrm{mL} / 100 \mathrm{~mL}$} \\
\cline { 2 - 5 } & 0.35 & 0.70 & 1.50 & 2.50 \\
\hline F. oxysporum & $23.22 \pm 3.29^{\mathrm{ab}, \mathrm{C}}$ & $23.98 \pm 0.15^{\mathrm{ab}, \mathrm{C}}$ & $60.16 \pm 1.46^{\mathrm{c}, \mathrm{C}}$ & $85.84 \pm 0.61^{\mathrm{d}, \mathrm{B}}$ \\
F. proliferatum & $24.06 \pm 4.20^{\mathrm{a}, \mathrm{C}}$ & $40.68 \pm 0.76^{\mathrm{b}, \mathrm{E}}$ & $72.21 \pm 0.83^{\mathrm{C}, \mathrm{A}}$ & $81.71 \pm 4.71^{\mathrm{d}, \mathrm{C}}$ \\
F. subglutinans & $22.30 \pm 0.79^{\mathrm{a}, \mathrm{C}}$ & $44.96 \pm 0.05^{\mathrm{b}, \mathrm{F}}$ & $76.45 \pm 5.63^{\mathrm{c}, \mathrm{A}}$ & $88.85 \pm 0.40^{\mathrm{d}, \mathrm{B}}$ \\
F. verticillioides & $11.14 \pm 1.25^{\mathrm{a}, \mathrm{A}}$ & $30.89 \pm 1.07^{\mathrm{b}, \mathrm{D}}$ & $72.61 \pm 1.15^{\mathrm{c}, \mathrm{A}}$ & $86.50 \pm 0.96^{\mathrm{d}, \mathrm{B}}$ \\
P. aurantiogriseum & $11.70 \pm 1.71^{\mathrm{a}, \mathrm{A}}$ & $54.47 \pm 0.52^{\mathrm{b}, \mathrm{A}}$ & $76.43 \pm 0.88^{\mathrm{c}, \mathrm{A}}$ & $100.00 \pm 0.00^{\mathrm{d}, \mathrm{A}}$ \\
P. glabrum & $3.07 \pm 1.09^{\mathrm{a}, \mathrm{B}}$ & $10.27 \pm 0.92^{\mathrm{b}, \mathrm{B}}$ & $53.74 \pm 0.96^{\mathrm{c}, \mathrm{B}}$ & $100.00 \pm 0.00^{\mathrm{d}, \mathrm{A}}$ \\
P. chrysogenum & $5.99 \pm 3.51^{\mathrm{a}, \mathrm{AB}}$ & $26.69 \pm 3.01^{\mathrm{b}, \mathrm{C}}$ & $57.73 \pm 2.25^{\mathrm{c}, \mathrm{BC}}$ & $86.20 \pm 0.34^{\mathrm{d}, \mathrm{B}}$ \\
P. brevicompactum & $11.61 \pm 1.26^{\mathrm{a}, \mathrm{A}}$ & $30.36 \pm 0.00^{\mathrm{b}, \mathrm{D}}$ & $62.86 \pm 3.03^{\mathrm{c}, \mathrm{C}}$ & $100.00 \pm 0.00^{\mathrm{d}, \mathrm{A}}$ \\
\hline
\end{tabular}

metulae and phialides, enlarged metulae, deformations of monophialides) and absence of reproductive organs (P. aurantiogriseum, $P$. brevicompactum, $P$. chrysogenum) were observed at the same concentrations.

Numerous studies of other researchers have also demonstrated considerable antifungal activity of dried oregano, oregano extracts and its essential oils. Akgula and Kivanc [26] found that, among ten tested spices, only oregano exerted antifungal activity against nine tested fungi. The addition of ground oregano and thyme into the growth medium reduced the production of aflatoxins by Aspergillus parasiticus [27]. Oregano extract at $2 \mathrm{~g} / 100 \mathrm{~g}$ completely inhibited the growth of $A$. parasiticus during 10 days of incubation at $30{ }^{\circ} \mathrm{C}$ [28]. Essential oil of oregano was described as a strong inhibitor of fungal growth and mycotoxin biosynthesis. In a 
growth medium that contained $0.10 \mathrm{~mL} / 100 \mathrm{~mL}$ oregano essential oil, the growth of $A$. parasiticus and aflatoxin production was completely inhibited [29]. Paster et al. [30] demonstrated the antifungal activity of oregano essential oil at concentration of 2.0 and 2.50 $\mu \mathrm{L} / \mathrm{L}$ on mycelium and spores of $A$. niger, $A$. flavus and A. ochraceus. Basilico and Basilico [31] reported that $1000 \mathrm{ppm}$ of oregano essential oils inhibited the growth of $A$. ochraceus and ochratoxin A production in YES broth during 21 days. Essential oils of Greek oregano at the applied concentration of $4 \mu \mathrm{L}$ significantly inhibited the growth of Pythium spp., Verticillium dahliae, Fusarium oxysporum f. sp. lycopersici and Sclerotina scleratiorum [32]. Etheric oil of oregano showed particularly strong inhibition to the growth of Fusarium proliferatum, F. graminearum and biosynthesis of fumonisin B1, zearalenone and deoxynivalenol [33,34]. Baratta et al. [35], Bouchra et al. [36] and Vuida-Martos et al. [37] implied that essential oil of oregano possesses stronger antifungal activity against $A$. niger and $A$. flavus in comparison to those of rosemary, sage, thyme and clove. Gumus et al. [38] reported that oregano essential oil completely inhibited the mycelial growth of Aspergillus fumigatus and Paecilomyces variotii at $0.25 \mathrm{~g} / 100 \mathrm{~g}$ during 10 days of incubation.

Antifungal activities of tested oregano extract depend on content of major and minor components. Thymol and carvacrol in concentration of $0.0025 \mathrm{~g} / 100 \mathrm{~g}$ and $0.05 \mathrm{~g} / 100 \mathrm{~g}$ at $\mathrm{pH} 5.5$ completely inhibited the growth of A. flavus, A. niger, Geotrichum candidum, Mucor spp., $P$. roqueforti and Penicillium spp. on PDA agar. The volatile oil Origanum syriacum that contain carvacrol and thymol as the major components completely inhibited the mycelial growth of $A$. niger, Penicillium spp., and $F$. oxysporum at concentration of 0.1 $\mu \mathrm{L} / \mathrm{mL}$ in YES broth [39].

At cellular level, these compounds are able to inhibit enzymes, possibly through reaction with sulfhydryl groups or through more nonspecific interactions with the proteins $[40,41]$. Their possible consequence is damage to membrane integrity, which could affect $\mathrm{pH}$ homeostasis and equilibrium of inorganic ions $[41,42]$.

\section{CONCLUSION}

The oregano extract at concentration of $2.50 \mathrm{~mL} / 100$ $\mathrm{mL}$ was found to efficiently reduce and inhibit the growth of assayed moulds. This concentration was MFC for P. aurantiogriseum and MIC for P. brevicompactum and $P$. glabrum. The growth of $P$. chrysogenum and Fusarium species was significantly reduced (81.69-88.84\%). The extract exerted stronger effect on the Penicillium species. Among Penicillium species, $P$. aurantiogriseum was the most sensitive to the extract whereas $P$. chrysogenum was the least sensitive. F. subglutinans showed higher sensitivity to the extract activity in relation to other Fusarium species whereas F. proliferatum had the lowest sensitivity.

The obtained results suggest that the oregano extract is suitable as antifungal agent in food applications. However, additional research is necessary to assess more in detail the practical application of the tested concentrations in the real food system (e.g., bakery products).

\section{Acknowledgments}

The study is the part of the investigations realized within the scope of the Project No. TR 31017 financially supported by the Ministry of Science and Technological Development of the Republic of Serbia.

\section{REFERENCES}

[1] E.P. Nelson, A.T. Toussoun, O.F.W. Marasas, Fusarium species. An illustrated Mmnual for identification, The Pennsylvania State University Press, University Park and London, 1983.

[2] J. Lević, S. Stanković, A. Bočarov-Stančić, M. Škrinjar, Z. Mašić, The Overview on Toxigenic Fungi and Mycotoxins in Serbia and Montenegro, in: An Overview on toxigenic fungi and mycotoxins in Europe, A. Logrieco, A. Visconti (Eds.), Kluwer Academic Publishers, Dordrecht, Boston, London, 2004, pp. 201-218.

[3] F.J. Leslie, A.B. Summerell, The Fusarium Laboratory Manual, Blackwell Publishing, USA, 2006.

[4] T.J. Lević, Vrste roda Fusarium, Institut za kukuruz "Zemun Polje" i Društvo genetičara Srbije, Cicero, Beograd, 2008.

[5] J.I. Pitt, A.D. Hocking, Fungi and Food Spoilage, $2^{\text {nd }}$ ed., Blackie Academic \& Profesional, London, 1997.

[6] A.R. Samson, C.J. Frisvad, Penicillium subgenus Penicillium: new taxonomic schemes, mycotoxins and other extrolites, Centraalbureau vor Schimmelcultures, Ultech, 2004.

[7] O. Filtenborg, J.C. Frisvad, A.R. Samson, Specific association of fungal to foods and influence of physical environmental factors, in: Introduction to food-borne fungi, R.A. Samson, E.S. van Reen-Hoekstra (Eds.), Centraalbureau voor Shimmelcultures, Baarn-Delft, The Netherlands, 2004, pp. 306-320.

[8] T. Montville, K. Matthews, Food microbiology an introduction, ASM Press, Washington, USA, 2005, pp. 241-261 .

[9] CAST, Mycotoxins: risks in plant, animal, and human systems, Ames, lowa, USA, 2003, pp. 20-86.

[10] J.C. Frisvad, U. Thrane, Mycotoxin production by common filamentous fungi, in: Introduction to food-borne fungi, A.R. Samson, E.S., van Reen-Hoekstra (Eds.), Centraalbureau voor Shimmelcultures, Baarn-Delft, 2004, pp. 321-331.

[11] D. Diaz, The Mycotoxin Blue Book, Nottingham University Press, Nottingham, 2005, pp. 93-139. 
[12] S. Burt, Essential oils: their antibacterial properties and potential applications in foods-a review, Int. J. Food Microbiol. 94 (2004) 223-253.

[13] F. Bakkali, S. Averbeck, D. Averbeck, M. Idaomar, Biological effects of essential oils - a review, Food Chem. Toxicol. 46 (2008) 446-475.

[14] D.S. Kocić-Tanackov, R.G. Dimić, N.A. Tepić, L.B. Vujičić, Influence of Allium ampeloprasum L. and Allium cepa L. essential oils to growth of some yeasts and moulds, Proc. Nat. Sci. Matica Srpska 116 (2009) 121-130.

[15] E.M. Fawzi, A.A. Khalil, A. F. Afifi, Antifungal effect of some plant extracts on Alternaria alternata and Fusarium oxysporum, Afr. J. Biotechnol. 8 (2009) 2590-2597.

[16] L. Alpsoy, Inhibitory effect of essential oil on aflatoxin activities, Afr. J. Biotechnol. 9 (2010) 2474-2481.

[17] M.M. Tajkarimi, S.A. Ibrahim, D.O. Cliver, Antimicrobial herb and spice compounds in food, Food Contr. 21 (2010) 1199-1218.

[18] R.A. Samson, E.S. Hoekstra, J.C. Frisvad, Introduction to food-borne fungi, Centraalbureau voor Shimmelcultures Baarn-Delft, 2004.

[19] D.K. Pandey, N.N. Tripathi, R.D. Tripathi, S.N. Dixit, Fungitoxic and phytotoxic properties of the essential oil of Caesulia axillaris Roxb. (Compositae), J. Appl. Bot. 56 (1982) 256-257.

[20] N. Arnold, B. Bellomaria, G. Valentini, Composition of essential oil of three different species of Origanum in the eastern Mediterranean, J. Essent. Oil Res. 12 (2000) 192-196.

[21] K. Veres, E. Varga, A. Dobos, Z. Hajdu, I. Mathe, E. Nemeth, K. Szabo, Investigation of the composition and stability of the essential oils of Origanum vulgare ssp. vulgare L. and O. vulgare ssp. hirtum (Link) letswaart, Chromatographia 57 (2003) 95-98.

[22] A. Lopez, S.M. Alzamora, E. Palou, Aspergillus flavus growth in the presence of chemical preservatives and natural occurring antimicrobial compounds, Int. J. Food Microbiol. 99 (2005) 119-128.

[23] B. Lukas, C. Schmiderer, C. Franz, J. Novak Composition of essential oil compounds from dsifferent Syrian populations of Origanum syriacum L. (Lamiaceae), J. Agr. Food Chem. 57(2009) 1362-1365.

[24] A. Sivropoulou, E. Papanikolaou, C. Nikolaou, S. Kokkini, T. Lanaras, M. Arsenakis, Antimicrobial and cytotoxic activites of origanum essential oils, J. Agr. Food Chem. 44 (1996) 1202-1205.

[25] H.J.D. Dorman, S.G. Deans, Antimicrobial agents from plants: antibacterial activity of plant volatile oils, J. Appl. Microbiol. 88 (2000) 308-316.

[26] A. Akgul, M. Kivanc, Inhibitory effects of selected Turkish spices and oregano components on some foodborne fungi, Int. J. Food Microbiol. 6 (1988) 263-268.

[27] J. Salmeron, R. Jordano, R. Pozo, Antimycotic and antiaflatoxigenic activity of oregano (Origanum vulgare L.) and thyme (Thymus vulgaris L.), J. Food Protect. 53 (1990) 697-700.

[28] M. Özcan, Inhibitory effect of spices extracts on the growth of Aspergillus parasiticus NRRL2999 strain, Eur. Food Res. Tech. 207 (1998) 253-255.
[29] A. Tantaoui-Elaraki, L. Beraoud, Inhibition of growth and aflatoxin production in Aspergillus parasiticus by essential oils of selected plant materials, J. Environ. Pathol. Toxicol. Oncol. 13 (1994) 67-72.

[30] N. Paster, M. Menasherov, U. Ravid, B. Juven, Antifungal activity of oregano and thymi essential oils applied as fumigants against fungi attacking store grain, J. Food Protect. 58 (1995) 81-85.

[31] M.Z. Basilico, J.C. Basilico, Inhibitory effects of some spice essential oils on Aspergillus ochraceus NRRL 3174 growth and ochratoxin A production, Lett. Appl. Microbiol. 23 (1999) 238-241.

[32] E. Wogiatzi, N. Gougoulias, A. Papachatzis, I. Vagelas, N. Chouliaras, Greek oregano essential oils production, phytotoxicity and antifungal activity, Biotechnol. \& Biotechnol. Eq. 23 (2009) 1150-1152.

[33] A. Velluty, V. Sanchis, A.J. Ramos, J. Egido, S. Marin, Inhibitory effect of cinnamon, clove, lemongrass, oregano and palmarose essential oils on growth and fumonisin B1 production by Fusarium proliferatum, Int. J. Food Microbiol. 89 (2003) 145-154.

[34] A. Velluty, V. Sanchis, A.J. Ramos, C. Turon, S. Marin, Impact of essential oils on growth rate, zearalenone and deoxynivalenol production by Fusarium graminearum under different temperature and water activity conditions in maize grain, J. Appl. Microbiol. 96 (2004) 716$-724$.

[35] M.T. Baratta, H.J.D. Dorman, S.G. Deas, D.M. Biondi, G. Ruberto, Chemical composition, antimicrobial and antioxidative activity of laurel, sage, rosmary, oregano and coriander essential oils, J. Essent. Oil Res. 10 (1998) 618-627.

[36] C. Bouchura, M. Achouri, I.L.M. Hassani, M. Hmamouchi, Chemical composition and antifungal activity of essential oils of seven Moroccan labiate against Botrytis cinerea Pers: Fr., J. Ethnopharmacol. 89 (2003) 165-169.

[37] M. Viuda-Martos, Y. Ruiz-Navajas, J. Fernández-López, J. Pérez-Álvarez, Antifungal activities of thyme, clove and origano essential oils, J. Food Safety 27 (2007) 91-101.

[38] T. Gumus, A. Sukuru Demirci, O. Sagdic, M. Arici, Inhibition of heat resistant molds: Aspergillus fumigatus and Paecilomyces variotii by some plant essential oils, Food Sci. Biotechnol. 19 (2010) 1241-1244.

[39] [39] R.K. Daouk, S.M. Dagher, E.J. Sattout, Antifungal activity of the essential oil of Origanum syriacum L., J. Food Protect. 58 (1995) 1147-1149.

[40] M.M. Cowan, Plant production as antimicrobial agents, Clin. Microbiol. Rev. 12 (1999) 564-568.

[41] J.S. Dambolena, M.P. Zunino, A.G. López, H.R. Rubinstein, J.A. Zygadlo, J.W. Mwangi, G.N. Thoithi, I.O. Kibwage, J.M. Mwalukumbi, S.T. Kariuki, Essential oils composition of Ocimum basilicum L. and Ocimum gratissimum L. from Kenya and their inhibitory effects on growth and fumonisin production by Fusarium verticillioides, Innovat. Food Sci. Emerg. Tech. 11 (2010) 410-414.

[42] R.J.W. Lambert, P.N. Skandamis, P.J. Coote, G.J.E. Nychas, A sudy of the minimum inhibitory concentration and mode of action of oregano essential oil, thymol and carvacrol, J. Appl. Microbiol. 91 (2001) 453-462. 


\section{IZVOD}

\section{ANTIFUNGALNA AKTIVNOST EKSTRAKTA ORIGANA (Origanum vulgare L.) NA RAST Fusarium I Penicillium VRSTA IZOLOVANIH IZ HRANE}

Sunčica D. Kocić-Tanackov ${ }^{1}$, Gordana R. Dimić ${ }^{1}$, Ilija J. Tanackov ${ }^{2}$, Dušanka J. Pejin ${ }^{1}$, Ljiljana V. Mojović ${ }^{3}$, Jelena D. Pejin $^{1}$

${ }^{1}$ Univerzitet u Novom Sadu, Tehnološki fakultet, Novi Sad, Srbija

${ }^{2}$ Univerzitet u Novom Sadu, Fakultet tehničkih nauka, Novi Sad, Srbija

${ }^{3}$ Univerzitet u Beogradu, Tehnološko-metalurški fakultet, Beograd, Srbija

(Naučni rad)

$\mathrm{U}$ radu je prikazan uticaj ekstrakta origana (Origanum vulgare L.) na rast $\mathrm{Fu}$ sarium i Penicillium vrsta izolovanih iz kolača i salata od svežeg povrća. Antifungalna ispitivanja su izvedena metodom agar ploča. Sastav aktivnih komponenti ekstrakta je određen GC-MS metodom i kao glavne komponente ustanovljene su: karvakrol (34,2\%), karvon (18,5\%) i $p$-cimen $(8,05 \%)$. Ispitivani ekstrakt je na svim primenjenim koncentracijama pokazao sposobnost redukcije rasta plesni. Jači inhibitorni efekat je utvrđen na rast Penicillium vrsta. Pri koncentraciji od 2,50 mL/ $/ 100 \mathrm{~mL}$ ekstrakta rast $P$. aurantiogriseum, $P$. glabrum i $P$. brevicompactum je kompletno inhibiran tokom 14 dana inkubiranja. Pri istoj koncentraciji rast $F$. proliferatum je inhibiran za $81,71 \%$, F. oxysporum za $85,84 \%$, F. verticillioides za $86,50 \%$, P. chrysogenum za $86,2 \%$ i $F$. subglutinans za $88,85 \%$. Ispitivani začinski ekstrakt origana je pored ograničavanja rasta kolonija plesni uzrokovao i promene u makro- i mikromorfologiji. Pri višim koncentracijama (1,50 i 2,50 mL/100 mL) došlo je do formiranja nekarakterističnih, kolonija sa izdignutim centrom, zrnaste strukture i smanjenom konidijacijom ( $P$. brevicompactum, $P$. chrysogenum, $F$. oxysporum). Takođe, na ovim koncentracijama su u mikroskopskom preparatu uočene deformacije hifa (sa čestom fragmentacijom i zadebljanjima, ugibanje) i reproduktivnih organa (vezikule nepravilnog oblika, često bez metula i fijalida, pojava proširenih metula, deformacija monofijalida) ili bez reprouktivnih organa ( $P$. aurantiogriseum, $P$. brevicompactum i $P$. chrysogenum). Rezultati pokazuju da bi ispitivani ekstrat origana mogao imati zaštitni efekat u kontroli rasta plesni u hrani tokom čuvanja ili čak produžiti rok trajnosti hrane.

Ključne reči: Ekstrakt origana • Antifungalni uticaj • Fusarium spp. • Penicillium spp. 